\title{
Influence of Credit Risk on Financial Performance of Deposit Taking Microfinance Banks in Kenya
}

\section{Abunda Joshua, Tobias Olweny, Margret Oloko}

To Link this Article: http://dx.doi.org/10.6007/IJARAFMS/v11-i4/11706 DOI:10.6007/IJARAFMS /v11-i4/11706

Received: 11 October 2021, Revised: 11 November 2021, Accepted: 29 November 2021

Published Online: 16 December 2021

In-Text Citation: (Joshua et al., 2021)

To Cite this Article: Joshua, A., Olweny, T., \& Oloko, M. (2021). Influence of Credit Risk on Financial Performance of Deposit Taking Microfinance Banks in Kenya. International Journal of Academic Research in Accounting Finance and Management Sciences, 11(4), 82-98.

Copyright: (c) 2021 The Author(s)

Published by Human Resource Management Academic Research Society (www.hrmars.com)

This article is published under the Creative Commons Attribution (CC BY 4.0) license. Anyone may reproduce, distribute, translate and create derivative works of this article (for both commercial and non-commercial purposes), subject to full attribution to the original publication and authors. The full terms of this license may be seen

at: http://creativecommons.org/licences/by/4.0/legalcode

Vol. 11, No. 4, 2021, Pg. 82 - 98

Full Terms \& Conditions of access and use can be found at http://hrmars.com/index.php/pages/detail/publication-ethics 


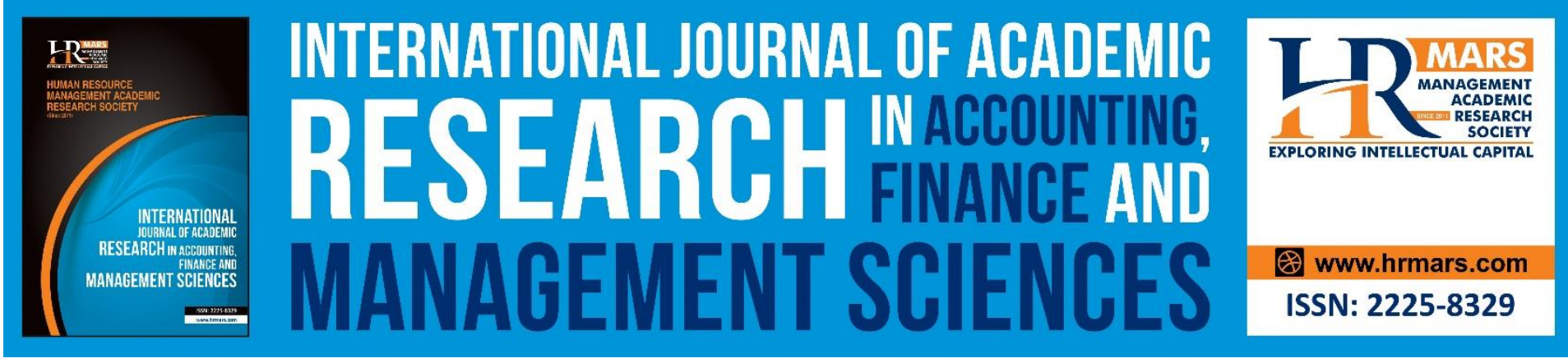

\title{
Influence of Credit Risk on Financial Performance of Deposit Taking Microfinance Banks in Kenya
}

\author{
Abunda Joshua, Dr. Tobias Olweny, Prof. Margret Oloko
}

Department of Economics and Accounting, School of Business and Entrepreneurship, Jomo

Kenyatta University of Agriculture and Technology, Nairobi, Kenya

Email: josabunda@gmail.com

\begin{abstract}
Deposit taking microfinance banks plays a major role in boosting the economy of a country, improving the standard of living of people and alleviating poverty more especially in developing countries. The study sought to determine the influence of credit risk on financial performance of deposit taking microfinance banks in Kenya. The independent variable in this study was credit risk proxied by Capital to risk weighted assets and non-Performing loan ratio while dependent variable was financial performance measured by return on equity. The study adopted Panel data regression using ordinary Least Squares (OLS) methods/ design. The target population of the study was 13 deposit taking microfinance banks regularized and licensed by Central Bank of Kenya (CBK) by 2017. However due to insufficient data (information) 4 Deposit taking microfinance banks were removed. The study analyzed 9 Banks s for the period of 7 years (2011 to 2017). Secondary data was used in order to capture the relationship between credit risk and performance of deposit taking microfinance banks in Kenya. The data was analyzed using Descriptive statistics, correlation analysis and panel regression analysis. Statistical software's Eview version 8 was used to estimate the relationship between the study variables. The autocorrelation among the regression model was tested using Durbin-Watson factors. The augmented Dickey Fuller (ADF) unit root test was used with the null hypothesis for acceptance (non-stationarity) or rejection (stationality). Regression result indicated that credit risk had a positive and statistically significant effect on financial performance of deposit taking microfinance banks in Kenya. The study recommends that further studies should be conducted to determine the effect of credit on financial performance of deposit taking microfinance banks using more credit variables and longer time of period, in addition there is need to analyze the influence of credit risk on other financial institutions like SACCOs and commercial banks. Furthermore, researches on other risks which include, market risk, interest rate risk, liquidity risk, strategic, Compliance and legal needs to be investigated since they are not included in the study.
\end{abstract}

Keyword: Credit Risk, Capital to Risk Weighted Assets, Non-Performing Loan Ratio, Deposit Taking Microfinance Banks, Financial Performance 
MANAGEMENT SCIENCES

Vol. 11 , No. 3, 2021, E-ISSN: 2225-8329 @ 2021 HRMARS

\section{Introduction}

\section{Background}

The concept of Microfinance banks in Kenya is believed to be a big boost to the poor people and is one of the developed in the sub-Saharan Africa. The Kenyan government enacted the microfinance act in the year 2006 which became operational 2nd May 2008 with the aim of improving the profitability, standard of living, improving the economy of the borrowers and the country at large. However, despite the enactment of the Act, deposit taking microfinance banks, financial performance has consistently been declining with cases of credit risk reported. Microfinance banks, profit before tax decreased by $41 \%$ from Ksh 1,002 million for the period ending December 2014 to Ksh 592 million for the period ended December 2015. As result, Return on Equity declined from 10\% in 2014 to 5\% in 2015 (CBK, 2015). The microfinance banks ratio of core capital to risk assets decreased from $22 \%$ to $21 \%$ and was above minimum requirement of $10 \%$. The microfinance banks profit before tax decreased by 169 percent from Ksh 549 million for the period ended December 2015 to a loss of Kshs.377 million for the period ended December 2016. Net non-performing loans increased by $94 \%$ as at 31 December 2016. Overall decline performance with a combined loss before tax of 622 million for the year ending 31 December 2017 was also reported by the central bank of Kenya (CBK, 2017). This was as a result of the registered loss of Kshs 377 reported by the microfinance sector. The overall declining in performance of MFBs is a prove that credit risk is one of the significant risks which raises concern on how it's management. Past empirical studied have been carried out in relation to credit risk and financial performance of deposit taking microfinance banks/ or firms. These are (Fredrick, 2012; Gatuhu, 2013; Murage, 2014; Kariuki, 2017) showed a positive significance relationship between credit risk and financial performance while (Muriithi et al., 2016) had negative findings between credit risk and organizational performance.

Therefore, there is no consensus of the findings and this one necessitates this study on credit risk on financial performance of deposit taking microfinance banks in Kenya.

\section{Statement of the Problem}

Despite the enactment of the Act, deposit taking microfinance banks, financial performance has consistently been declining with cases of credit risk reported. Microfinance banks, profit before tax decreased by 41\% from Ksh 1,002 million for the period ending December 2014 to Ksh 592 million for the period ended December 2015. As result, Return on Equity declined from 10\% in 2014 to $5 \%$ in 2015 (CBK, 2015). The microfinance banks ratio of core capital to risk assets decreased from $22 \%$ to $21 \%$ and was above minimum requirement of $10 \%$. The microfinance banks profit before tax decreased by 169 percent from Ksh 549 million for the period ended December 2015 to a loss of Kshs.377 million for the period ended December 2016. Net non-performing loans increased by $94 \%$ as at 31 December 2016. Overall decline performance with a combined loss before tax of 622 million for the year ending 31 December 2017 was also reported by the central bank of Kenya. This was as a result of the registered loss of Kshs 377 reported by the microfinance sector. The overall declining in performance of MFBs is a prove that credit risk is one of the significant risks which raises concern on how it's management.

Past empirical studies have been carried out in relation to credit risk and financial performance of deposit taking microfinance banks/ or firms. These are (Fredrick, 2012; Gatuhu, 2013;. Murage, 2014; Kariuki, 2017) showed a positive significance relationship 
MANAGEMENT SCIENCES

Vol. 11, No. 3, 2021, E-ISSN: 2225-8329 @ 2021 HRMARS

between credit risk and financial performance while (Muriithi et al., 2016) had negative findings between credit risk and organizational performance.

Therefore, there is no consensus of the findings and this one necessitates this study on the influence of credit risk on financial performance of deposit taking microfinance banks in Kenya.

\section{General Objective}

The general objective of this study was to determine the influence of credit risk and financial performance of the Microfinance Banks in Kenya.

\section{Specific Objectives}

The research study pursues the following specific objectives:

To determine the extent to which the capital to risk weighted assets influences the financial performance of the deposit taking Microfinance Banks in Kenya

To examine the influence of non-performance loans ratio on financial performance of deposit taking Microfinance Banks in Kenya.

\section{Research Hypothesis}

This research sought to address the following pertinent research hypothesis:

$\mathrm{Ho}_{1}$ : Credit risk has no significant influence on financial performance of the deposit taking Microfinance Banks in Kenya.

\section{Justification}

The study of credit risk is very relevant to both researcher and managers. The major study issue faced by the finance managers to receive and keep funds received from depositors but also their deployment to borrowers in a meaningful way in order to generate better returns. Banks receive their funds in almost the same way, but however why some business fail and others succeed is an issue. This means that there is something beyond which needs to be researched on. This therefore, justifies this research study influence of credit risk on financial performance of deposit Taking microfinance banks in Kenya.

\section{Definition of Terms}

Deposit-taking microfinance: According to ROK, (2006) Means a microfinance business in which the person operating the business holds himself put as accepting deposits on a day-today basis.

Financial Performance: Means the process of measuring the results of a firm's policies and operations in monetary terms over a given period of time.(Erasmus, 2008).

Return on Equity: Ongore \& Kusa, (2013) Means a financial ratio that refers to how much profit a company earned compared to total amount of shareholder equity invested or found on the balance sheet.

Credit risk: Is defined as the degree of value fluctuation in debt instruments and derivatives due to changes in the underlying credit quality of borrowers and counterparties (Chen \& Pan, 2012). 
MANAGEMENT SCIENCES

Vol. 11, No. 3, 2021, E-ISSN: 2225-8329 @ 2021 HRMARS

\section{Literature Review}

\section{Theoretical Literature Review}

Loanable Fund Theory

Loanable fund theory of interest rate owes its origin to Knut Wicksell a Swedish economist. Later on, economists like Ohlin, Myrdal, Lindahl, Robertson and J. Viner have considerably contributed to this theory. According to this theory, rate of interest is determined by the demand for and supply of loanable funds. Wilson et al (2011); Goddard et al (2010) concluded that the importance of capital base is a meaningful capital standard which protect the taxpayers and the stability of financial systems of a firm. Retained earnings of the shareholder, form a key component of capital hence an important source of loanable funds in microfinance banks. It has been acknowledged that loanable funds theory is the funds which have been made available to be borrowed due to changes in government laws and interest rate (Saunders \& Cornett, 2007). In Microfinance banks, loanable funds theory refers to the money available to be borrowed as deposited by members in banks. The retained money in microfinance banks have highly assisted the ever-growing number of poor people by meeting their demand for the loans to invest.

Regulator acknowledge the owners contributions as important, because it is the total amount of money which is available to stakeholders in the event of insolvency and liquidation (Saunders \& Cornett, 2007). According to Bhattacharya and Thakor, 1993, High capital ratios are normally fixed by financial institutions; this is to cushion depositors against any loss and any panic withdrawals which may lead to destructive panic runs on other solvent but illiquid microfinance banks.

Microfinance banks are faced with exposer of various credit risks among them nonperforming loans and capital to risk weighted assets. in credit risk the management of the bank as a lender is uncertain if borrower will repay the loan as per the documentation in the application forms (David et al., 2014). For capital to weighted risk (Mishkin \& Eakins, 2012) argues that the more capital should pumped into the investment of assets which are expected to generate more income for the deposit taking microfinance banks.

\section{Empirical Literature Review}

A few empirical studies have been done to analyze the relationship between credit risk and financial performance of deposit taking microfinance banks. Gatuhu (2013) Sought to determine the effect of credit management on the financial performance of Microfinance Institutions in Kenya. Descriptive survey design was used. The target population comprised of 59 MFIs in Kenya that are members of AMFI. A census study was used. Primary data was collected using questionnaires. Descriptive statistics were used to analyze data. The study found out that client appraisal, credit risk control and collection policy significantly influence financial performance and that stringent policy is more effective in debt recovery than a lenient policy.

Kibui (2014) Studied the effect credit risk management practices on financial performance of Harambee Sacco. Specifically, the investigated the effect of client appraisal methods, credit policy formulation, modern credit risk monitoring and control methods and systematic defaulter follow-up and loan defaulter reports on financial performance of SACCOs. Descriptive research method was used. The target population of this study 178 credit officers of whom the researcher took 58 respondents. Harambee SACCO, Nairobi. Simple random sampling technique was used. The study found out that Sacco used guarantors, collaterization, shareholding and insurance as risk mitigation strategies in credit risk 
MANAGEMENT SCIENCES

Vol. 11, No. 3, 2021, E-ISSN: 2225-8329 @ 2021 HRMARS

management. The study also found out that credit risk management help to improve the performance of Saccos to great extent. Additionally, the study found out that there was a customized computer-based reporting system which allow for detection of overdue loans in the shortest possible time

(David et al., 2014) examined the impact of non-performing loan on financial performance of Microfinance Banks in Kenya: The study was conducted to survey the microfinance banks in Nakuru town, Kenya. The study was guided by credit risk as an in depended variable and financial performance as the dependent variable. The study adopted descriptive research design. The target population of the study comprised of 66 credit and management personnel of the surveyed Microfinance banks (MFBs) within Nakuru town. The study used a census survey an implication that no sampling was done. In collecting data from the respondents, a structured questionnaire used. A pilot study was conducted prior to undertaking the amin study. The main aim of conducting a pilot study was to test and verify the instrument's reliability and validity. The study sought to find out both the content validity of the instrument. Cronbach alpha was used to reliability. The collected data was analyzed by both descriptively and inferentially. Descriptive analysis was to present the opinions of the respondents under study regarding study constructs. Inferential analysis on the other hand enabled making the deductions pertinent to nonperformance loans and financial performance of microfinance banks in Nakuru town. The study research findings were presented in form of descriptive and inferential statistical tables. it was established through findings that credit risk significantly affected financial performance of MFBs in Nakuru town. The credit risk negated the MFBs, financial performance. The study recommended that; potential borrowers should be critically analyzed to assess their credit worthiness before they are awarded loans.

Murage (2014) examined the effect of credit risk on corporate liquidity of Deposit Taking Microfinance institutions (DTMs) in Kenya. The research used descriptive research. The population of the study comprised of all the nine DTMs in Kenya for a period of three years (2000-2003). The finding of the study indicated that credit risk has a strong and a statistically significant effect on corporate liquidity of deposit taking microfinance institutions in Kenya.

Muturi (2016) analyzed the effect of credit management practices on loan performance in deposit taking microfinance bank in Kenya. Descriptive research design was adopted. The study targeted sampled employees of DTMIs who classified into three sectors top level middle level and lower level. The target population consisted of 10 deposit taking MFIs. Primary data was collected by use of structured questionnaire. Secondary data was obtained from financial reports of microfinance institutions documented by Central bank of Kenya (CBK). Primary data was analyzed using statistical measures of mean and standard deviation. Further the study used inferential statistics of multiple regression models. The models were used to determine the relative effect of credit risk management practices on loan repayment. The finding established that credit standards, credit policy, credit items and collection policy affect the organizational performance.

Kariuki (2017) established the effect of credit risk management practices on financial performance of deposit taking SACCOSs in Kenya by adopting descriptive research. The population comprised of 164 SAACOs registered under SASRA. Based on the objectives, credit risk identification, credit analysis practices, credit monitoring and credit mitigation measures, the study concluded that credit analysis, credit mitigation measures and credit identification have a significant positive effect on financial performance. The study recommended that SACCOs should have stringent credit analysis techniques and that also adopt credit 
MANAGEMENT SCIENCES

Vol. 11, No. 3, 2021, E-ISSN: 2225-8329 @ 2021 HRMARS

monitoring practices. The study also recommended that that SACCOs and many other lending organizations should have a stringent credit mitigation measure and policies. Therefore, the credit committees at all levels must work in co-ordination in order to ensure that credit is collected in a timely manner.

Kitonyi (2019) Investigated non-performing loans and financial performance of microfinance institutions (MFI) IN Kenya. The specific objective of the study included to assess the effect of non-performing loan ratio (NPL), examine the effect of loan loss provision (LLP), evaluate the effect of cost per loan asset ratio (CLAR), and establish the fact of credit to deposit ratio (CDR) on financial performance of Microfinance institutions in Kenya. The study employed descriptive design and utilized cross-sectional data for a period of five years (2013-2017). The target population of the was four selected Microfinance banks operating in Kenya. The microfinance was licensed to accept deposits and to perform lending business. The study used census method to the study sample. The study used Secondary data specifically, annual published financial statements and other financial records from the Central Bank of Kenya (CBK). In order to establish non-performing statistics, Microfinance Excel and SPSS software's were used. At the same time regression analysis of SPSS was used to establish the effect of non-performing loans (NPLS) on financial performance of MFIs in Kenya. The findings of the study overall established that, financial performance of Microfinance banks (MFBs) is significantly and positively affected by nonperforming loans in various proportion despite loans being the main asset that that generates income. The study established that financial performance of MFIs is significantly and positively affected by nonperforming loans in various proportions despite loans being the main asset that generates income.

\section{Conceptual Framework}

\section{Dependent and Independent Variable}

A conceptual framework is a tool in a study that a researcher develops to bring awareness and a common understanding of the area or situation under investigation and hence communicate it. When it is well articulated, it assists a researcher to make meaning of subsequent findings of a research study According to Smith (2004), says that a conceptual framework forms part of the agenda for negotiations to be scrutinized, tested, reviewed and reformed as a result of investigation and it explains the possible connections between the variables. As noted by Smith (2004) a well-presented conceptual framework helps to explain the possible connections between the variables.

The dependent variable used in this study is the financial performance of deposit taking microfinance banks in Kenya. The financial performance will be measured by Return on Equity. In this study we use credit risk as independent variable which is measured by capital risk weighted assets and non-performing loan ratio. The following equation is used to explain the relationship between the dependent and independent variable:

Financial performance $=a+b($ credit risk $)+e$ 
MANAGEMENT SCIENCES

Vol. 11, No. 3, 2021, E-ISSN: 2225-8329 @ 2021 HRMARS

\title{
Conceptualization
}

Independent Variable

Credit Risk

\author{
Dependent Variable \\ Financial Performance
}

- Capital to risk weighted assets

- Non-Performing loan ratio

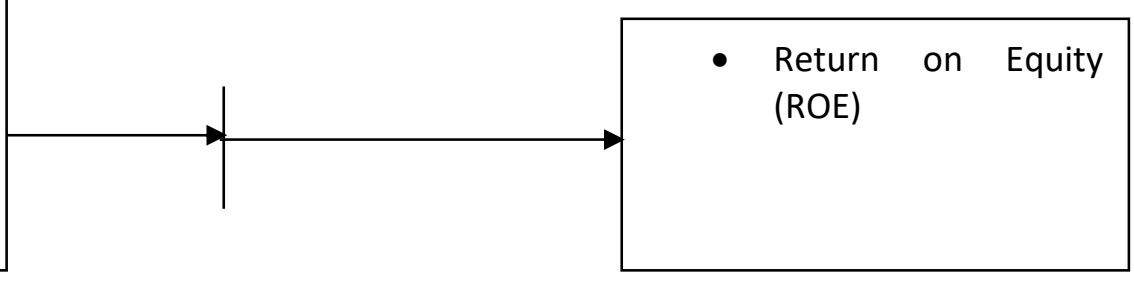

\section{Research Methodology \\ Introduction}

This chapter comprised of the research methodology as it was applied in undertaking the study, data was collected, data analysis and data interpretation was undertaken Below are the outlined activities as they were carried out.

\section{Research Design}

A research design is the overall plan for obtaining answers to the questions being investigated and for handling some of the challenges encountered by the researcher during the research process (Polit \& Beck, 2003). The study adopted panel data estimation technique because it took care of heterogeneity association with individual deposit taking microfinance banks (DTMBs) by allowing for individual specific variables for the period 2008 and 2017.

\section{Target Population}

The target population of the study is the 13 deposit taking microfinance banks in Kenya which operates and has been regularized by the Centra Bank of Kenya.

\section{Data Collection Instrument}

The secondary data was extracted from 13 deposit taking microfinance banks registered and regularized by the Centra Bank of Kenya (CBK) for Period of 10 years (2008-2017). However, 4 microfinance banks were removed because they were having insufficient data.

\section{Data Processing and Analysis}

Data analysis focuses on fulfilling the research objectives and provide answers to the research hypothesis. For the common man to understand the collected data easily, it requires to be analyzed.

The data collected was converted in excel format for easier arrangements into panels. The panels achieve better results since the researcher is able to control against unobserved heterogeneity while also giving a cross sectional and time-series dimension reducing the bias of the estimator (Kothari, 2012). According to Brooks (2008), panel data is a data which comprises both cross-sectional and times series characteristics. Panel data analysis is appropriate and significant for this study as it able to capture heterogeneity among the taking microfinance banks which are under study.

Descriptive statistics, correlation analysis, stationarity tests, multiple regression analysis and inferential statistics were conducted. Statistical software's EViews version 8 was used to estimate the relationship between the study variables. 
MANAGEMENT SCIENCES

Vol. 11, No. 3, 2021, E-ISSN: 2225-8329 @ 2021 HRMARS

dependent variable and Credit risk (CR) as a independent variable, The regression analysis was run by using E-Views 8 data analysis software.

The hypothesis was tested using the following regression model;

ROEit $=\alpha+\beta 1$ CRit $+\mu$ it

Where;

ROEit= Return on Equity at a time $t$

$\mathrm{CRit}=$ Credit risk ratio at time $\mathrm{t}$

$\alpha=$ is the intercept

$\beta 1=$ Is the parameter of predictor/explanatory variables of $C R$

$\mu$ it $=$ Is the disturbance term

The equation transformed is as follows;

LnROEit $=\alpha+\beta 1 C R$ it $+\mu$ it

Where;

$\mathrm{Ln} \quad=$ the natural logs of the variables

\section{Data analysis and Discussions}

\section{Introduction}

This chapter presents the results of data analysis. Secondary data of 13 deposit taking microfinance was obtained from published financial statements of the Central Bank of Kenya.

\section{Descriptive Statistics}

The data was converted to their natural logs to deal with the problem of large numbers and eliminate/ reduce heteroscedasticity. In table 1 the mean for capital risk weighted asset ratio indicated -1.116062, with a standard deviation of 0.848780 (from the mean -1.116062). The minimum and the maximum of -2.995732 and 1.131402 respectively. The finding shows that the deviations were not huge. The skewness coefficient (value) for capital risk weighted asset ratio is 0.495705 , indicating a that distribution data is moderately skewed since it is between 0.5 and 1. The Kurtosis coefficient (value) for capital risk weighted asset ratio was 3.477352 or $34 \%$ meaning that distribution was more than 3 and hence highly peaked than the normal distributed. This is a leptokurtic type of kurtosis where tails are also fatter than those of normal distribution. In finances it is used to measure financial risk. An investment leptokurtic distribution is said to be risk investment, but can also generate hefty returns to compensate for the risk. Jarque-bera value was 1.563896, this value is more and not close or closer to zero (0). This signifies that the curve for the variable is not normally distributed.

\section{Financial Performance}

Financial performance for this study was used as dependent variable and it was measured using Return on Equity. The study found that the ROE had a mean of -3.005357 , a minimum of -4.889943 , a maximum of -0.847299 and a standard deviation of 1.044469 . On average the finding reveals that ROE among the microfinance banks in Kenya is -3.005357 . This implies that the standard deviations from the mean is low for return on equity (ROE). The finding indicates that on average the deposit taking microfinance banks does not utilize owner's equity to generate net profit. The data did not exhibit normal distribution because the Skewness value of -0.045613 lied to the left during the period of study. The kurtosis value for ROE was 2.287672 (22\%) meaning that the distribution of data lowery peaked. Jarque-bera value was 0.666156 , this signifies a normally distributed curved variable. The probability was 0.716714 and is more than 0.1 . This means that the variable (ROE) was normally distributed. 
MANAGEMENT SCIENCES

Vol. 11, No. 3, 2021, E-ISSN: 2225-8329 @ 2021 HRMARS

\section{Non-performing Loans Ratio}

The mean for non-performing loans indicated -0.652126 , with a standard deviation of 0.848780 (from the mean -1.116062). The minimum and the maximum of -2.995732and 1.131402 respectively. The finding shows that the deviations were not huge. The skewness coefficient (value) for capital risk weighted asset ratio is 0.495705 , indicating a that distribution data is moderately skewed since it is between 0.5 and 1 . The Kurtosis coefficient (value) for capital risk weighted asset ratio was 3.477352 or $34 \%$ meaning that distribution was more than 3 and hence highly peaked than the normal distributed. This is a leptokurtic type of kurtosis where tails are also fatter than those of normal distribution. In finances it is used to measure financial risk. An investment leptokurtic distribution is said to be risk investment, but can also generate hefty returns to compensate for the risk. Jarque-bera value was 1.563896, this value is more and not close or closer to zero (0). This signifies that the curve for the variable is not normally distributed.

\begin{tabular}{|c|c|c|c|}
\hline & LN_ROE & LN_CRWA & LN_NPR \\
\hline Mean & $\begin{array}{l}- \\
3.005357\end{array}$ & -1.116062 & -0.652126 \\
\hline Median & $\begin{array}{l}- \\
2.888871\end{array}$ & -1.309333 & -0.465215 \\
\hline Maximum & $\begin{array}{l}- \\
0.847299\end{array}$ & 1.131402 & -0.042908 \\
\hline Minimum & $\begin{array}{l}- \\
4.889943\end{array}$ & -2.995732 & -2.207275 \\
\hline Std. Dev. & $\begin{array}{l}1.04446 \\
9\end{array}$ & 0.848780 & 0.488206 \\
\hline Skewness & $\begin{array}{l}- \\
0.045613\end{array}$ & 0.495705 & -1.354044 \\
\hline Kurtosis & $\begin{array}{l}2.28767 \\
2\end{array}$ & 3.477352 & 4.689288 \\
\hline Jarque-Bera & $\begin{array}{l}0.66615 \\
6\end{array}$ & 1.563896 & 13.15877 \\
\hline Probability & $\begin{array}{l}0.71671 \\
4\end{array}$ & 0.457514 & 0.001389 \\
\hline Sum & $\begin{array}{l}- \\
93.16608\end{array}$ & -34.59793 & -20.21591 \\
\hline Sum Sq. Dev. & $\begin{array}{l}32.7274 \\
8\end{array}$ & 21.61285 & 7.150346 \\
\hline Observations & 31 & 31 & 31 \\
\hline
\end{tabular}

Table 1 Descriptive Statistics of Credit risk Indicators Source: Author, Computation

In_crwa- Natural log of capital to risk weighted assets

In_npr - Natural log of non-performing loans ratio 


\section{Correlation Analysis}

The correlation coefficients of non-performing loans capital risk to weighted assets ratio were ---0.36 and -0.10 for non-performing loans respectively signifying weak negative correlations with return on equity. Therefore, it was expected that the coefficient of core capital to risk weighted assets and non-performing loans will be negative

\section{Table 2 Correlation Analysis}

\begin{tabular}{|c|c|c|c|}
\hline & LN_ROE & LN_CRWA & LN_NPR \\
\hline \multirow[t]{2}{*}{ LN_ROE } & 1.0000 & & \\
\hline & 00 & & \\
\hline \multirow[t]{2}{*}{ LN_BS } & 0.2825 & & \\
\hline & 65 & & \\
\hline \multirow[t]{3}{*}{ LN_CAR } & - & & \\
\hline & 0.26230 & & \\
\hline & 2 & & \\
\hline \multirow[t]{3}{*}{ LN_CIR } & - & & \\
\hline & 0.54890 & & \\
\hline & 5 & & \\
\hline \multirow[t]{3}{*}{ LN_CRWA } & - & 1.000000 & \\
\hline & 0.36105 & & \\
\hline & 1 & & \\
\hline \multirow[t]{3}{*}{ LN_LR } & - & 0.488375 & \\
\hline & 0.42422 & & \\
\hline & 6 & & \\
\hline \multirow[t]{3}{*}{ LN_NPR } & - & -0.041026 & 1.00000 \\
\hline & 0.10164 & & 0 \\
\hline & 1 & & \\
\hline \multirow[t]{3}{*}{ LN_TIL } & 0.3310 & -0.548100 & - \\
\hline & 55 & & 0.10478 \\
\hline & & & 0 \\
\hline
\end{tabular}

Unit Root Test at Intercept and Level (0)

\section{Return on Equity}

Return on equity was found to be stationary at intercept and level I (0) because the Levin, Lin \& Chu $t^{*}$ statistic had a probability value of 0.0046 which is significant at $1 \%$ level of significance. Therefore, we reject the null hypothesis that return on equity has a unit root. 


\begin{tabular}{|c|c|c|c|c|}
\hline Method & Statistic & Prob.** & $\begin{array}{l}\text { Cross- } \\
\text { sections }\end{array}$ & Obs \\
\hline \multicolumn{5}{|c|}{ Null: Unit root (assumes common unit root process) } \\
\hline Levin, Lin \& Chu t* & -2.60360 & 0.0046 & 5 & 20 \\
\hline \multicolumn{5}{|c|}{ Null: Unit root (assumes individual unit root process) } \\
\hline Im, Pesaran and Shin W-stat & -0.76760 & 0.2214 & 3 & 14 \\
\hline ADF - Fisher Chi-square & 10.6853 & 0.3826 & 5 & 20 \\
\hline PP - Fisher Chi-square & 14.4198 & 0.1547 & 5 & 20 \\
\hline
\end{tabular}

\section{Table 3: Unit Root Test on Return on Equity}

\section{Capital to Risk Weighted Assets}

Credit risk to weighted assets was found to be stationary at intercept and level I (0) because the Levin, Lin \& Chu t* statistic had a probability value of 0.0000 which is significant at $1 \%$ level of significance. Therefore, we reject the null hypothesis that credit risk to weighted assets has a unit root.

Table 4: Unit Root Test on Capital to Risk weighted Assets

\begin{tabular}{|c|c|c|c|c|}
\hline Method & Statistic & Prob.** & $\begin{array}{l}\text { Cross- } \\
\text { sections }\end{array}$ & Obs \\
\hline \multicolumn{5}{|c|}{ Null: Unit root (assumes common unit root process) } \\
\hline Levin, Lin \& Chu t* & -8.79253 & 0.0000 & 9 & 47 \\
\hline \multicolumn{5}{|c|}{ Null: Unit root (assumes individual unit root process) } \\
\hline Im, Pesaran and Shin W-stat & -2.91087 & 0.0018 & 8 & 44 \\
\hline ADF - Fisher Chi-square & 37.4399 & 0.0046 & 9 & 47 \\
\hline PP - Fisher Chi-square & 43.6126 & 0.0007 & 9 & 47 \\
\hline
\end{tabular}

\section{Non-Performing Loans Ratio}

Non-performing loans ratio was found to be stationary at intercept and level I (0) because the Levin, Lin \& Chu t* statistic had a probability value of 0.0000 which is significant at $1 \%$ level of significance. Therefore, we reject the null hypothesis that non-performing loans ratio has a unit root. 
Table 4: Unit Root Test on Non-performing loan ratio

\begin{tabular}{|c|c|c|c|c|}
\hline Method & Statistic & Prob.** & $\begin{array}{l}\text { Cross- } \\
\text { sections }\end{array}$ & Obs \\
\hline \multicolumn{5}{|c|}{ Null: Unit root (assumes common unit root process) } \\
\hline Levin, Lin \& Chu $\mathrm{t}^{*}$ & -5.17666 & 0.0000 & 9 & 45 \\
\hline \multicolumn{5}{|c|}{ Null: Unit root (assumes individual unit root process) } \\
\hline Im, Pesaran and Shin W-stat & -0.73649 & 0.2307 & 9 & 45 \\
\hline ADF - Fisher Chi-square & 25.4728 & 0.1124 & 9 & 45 \\
\hline PP - Fisher Chi-square & 32.4936 & 0.0192 & 9 & 45 \\
\hline
\end{tabular}

\section{Panel Regression Equation Hausman Test}

The Chi-square test statistic was 9.207812 with an insignificant probability value of 0.2381 which is insignificant at 5 percent level of significance. This therefore meant that the null hypothesis was rejected in favor of the Random effects model. Therefore, we accept the Random effects model as suitable for this study.

Correlated Random Effects - Hausman Test

Equation: Untitled

Test cross-section random effects

Test Summary

Chi-Sq.

Chi-Sq. d.f.

Prob.

Cross-section random

9.207812

7

0.2381

\section{Table 5: Correlation Random Effect- Hausman Test}

\section{Random effects model \\ Credit Risk}

Capital to risk weighted assets had a coefficient of -2.00 and a significant probability value of 0.0424 which is significant at 5 percent level of significance. This means that when capital to risk weighted assets decreases by 2 percent per year then return on equity increases by 1 percent in the same year.

\section{Study Hypothesis}

$\mathrm{H}_{\mathrm{o}}$ 2: Credit risk has no significant influence on financial performance of the deposit taking Microfinance Banks in Kenya. We reject the null hypothesis for CWRA that CRWA had no significant influence on financial performance of the deposit taking Microfinance Banks in Kenya during the period of study

Non-performing loans ratio had a coefficient of 0.33 and an insignificant probability value of 0.3252. This means that non-performing loans ratio had no significant effect on return on equity during the study period. They had a positive but insignificant relationship. 
MANAGEMENT SCIENCES

Vol. 11, No. 3, 2021, E-ISSN: 2225-8329 @ 2021 HRMARS

\section{Study Hypothesis}

$\mathrm{H}_{\mathrm{o}}$ 2: Credit risk has no significant influence on financial performance of the deposit taking Microfinance Banks in Kenya. We accept the null hypothesis that non-performing loans had no significant influence on financial performance of the deposit taking Microfinance Banks in Kenya during the period of study.

Other studies done as Engdawork (2014)reveal out that selected variables provision to total loans, loan to total asset, credit administration (cost to total loans) and size (Economies of scale) have significant effect on the performance of banks. Murage (2014) shows that credit risk has a strong and a statistically significant effect on corporate liquidity of deposit taking microfinance institutions in Kenya.

\section{Conclusion and Recommendations Conclusions}

The study has contributed to debate on credit risk management by adducing or bringing forward the influence of credit risk on financial performance of deposit taking Microfinance banks in Kenyan context. The findings of the study reveals that there was a weak negative correlation between credit risk and financial performance of deposit taking microfinance banks in Kenya unlike Murage (2014) who found strong and a statistically significant effect.

\section{Areas of Further Research}

The study recommends that there is need to analyze the effect of other banks risks which include, market risk, interest rate risk, liquidity risk, strategic, compliance and legal since they were not included in the study.

\section{References}

CBK. (2015). Supervision Annual Report.

CBK. (2017). Centra Bank of Kenya Supervision Annual Report 2017.

Chen, K.-C., \& Pan, C.-Y. (2012). An Empirical Study of Credit Risk Efficiency of Banking Industry in Taiwan. Web Journal of Chinese Management Review, 15(Febuary, 2012), 1-17. http://cmr.ba.ouhk.edu.hk

David, W., Nemwel, B., \& George, G. (2014). Impact of non-performing loans on financial performance of microfinance banks in Kenya. Int Researchernational Journal of Science And, 3(10), 2073-2078. https://doi.org/ISSN: 2319-7064

Engdawork Taddesse Awoke. (2014). Impact of credit risk on the performance of commercial banks in ethiopia (Issue December). St.Mary,s University School of Graduate Studies.

Erasmus, P. (2008). Evaluating value based financial performance measures. 7(March), 115118. http://ir1.sun.ac.za/handle/10019.1/1407

Fredrick, O. (2012). The Effect of Credit Risk Management on the Financial Performance of Commercial Banks in Kenya. DBA Africa Management Review, 1(1), 45-47. https://doi.org/10.5897/AJBM2013.7171

Gatuhu, R. (2013). The Effect of Credit Managementon the Financial Performance of Microfinance Institutions in Kenya. International Journal of Business and Social Research, 2(2), 3-5.

Hult, G. T. M., Mena, J. A., Ferrell, O. C., \& Ferrell, L. (2011). Stakeholder marketing: a definition and conceptual framework. AMS Review, 1(1), 44-65. https://doi.org/10.1007/s13162-011-0002-5

Kariuki, N. W. (2017). Effect of Credit Risk Management Practices on Financial Performance 
MANAGEMENT SCIENCES

Vol. 11 , No. 3, 2021, E-ISSN: 2225-8329 @ 2021 HRMARS

of Deposit Taking Savings and Credit Cooperatives in Kenya. IOSR Journal of Business and Management, 19(04), 63-69. https://doi.org/10.9790/487X-1904026369

Kibui, N. (2014). Effects of Credit Risk Management on Financial Performance of. International Academic Journal of Information Sciences and Project Management, 1(3), 157-172.

Kitonyi, S. W. (2019). Non-Performing Loans and Financial Performance of Microfinance Institutions in Kenya. The Strategic Journal of Business \& Change Management, 6(3), 840-848.

Mishkin, F. S., \& Eakins, S. G. (2012). Financial Markets and Institutions - Eighth Edition (N. Fentom (ed.); 7th ed.). Prentice Hall.

Murage, C. W. (2014). The Effect of Credit Risk on Corporate Liquidity of Deposit Taking in Kenya. East African Financial Review, 7(4), 37-46.

Muriithi, J. G., MunyuaWaweru, K., \& Muturi, W. M. (2016). Effect of Credit Risk on Financial Performance of Commercial Banks Kenya. IOSR Journal of Economics and Finance, 07(04), 72-83. https://doi.org/10.9790/5933-0704017283

Muturi, E. (2016). Effect of credit Management Practices on Loan Performance in Deposit Taking Microfinance Banks in Kenya. International Journal of Innovations, Business and Management (IJIBM), 10(1), 1-17.

Ohlin, B. (1937). the Stockholm Theory of Savings and Investment. Economic Journal, 47(185), 53-69.

Ongore, V. O., \& Kusa, G. B. (2013). Determinants of Financial Performance of Commercial Banks in Kenya. International Journal of Economics and Financial Issues, 3(1), 237-252. https://doi.org/10.15520/jbme.2015.vol3.iss11.158.pp33-40

Polit, D., \& Beck, C. (2003). (2003). Research principles and methods. Lippincott: (7th ed).

ROK. (2006). THE MICROFINANCE ACT, 2006 No. 19 of 2006. Nairobi: Goverment Printer, 19.

Saunders, Anthony and Cornett, M. M. (2007). Financial Markets and Institutions: An introduction to the risk management approach. McGraw-Hill.

Smith, K. A. (2004). Voluntarily reporting performance measures to the public a test of accounting reports from U.S. cities. International Public Management Journal, 7(1), 1948. https://doi.org/10.1080/17487870.2012.759422 
INTERNATIONAL JOURNAL OF ACADEMIC RESEARCH IN ACCOUNTING, FINANCE AND MANAGEMENT SCIENCES

Vol. 11, No. 3, 2021, E-ISSN: 2225-8329 @ 2021 HRMARS

\section{APPENDIX 1: DATA COLLECTION}

\begin{tabular}{|l|l|l|l|}
\hline Year & $\begin{array}{l}\text { Financial } \\
\text { Performance }\end{array}$ & $\begin{array}{l}\text { Regulatory } \\
\text { capital adequacy }\end{array}$ & CBK Regulations \\
\hline & $\begin{array}{l}\text { Return on Equity } \\
\text { net income } \\
\text { shareholder's } \\
\text { equity }\end{array}$ & $\begin{array}{l}\text { Capital adequacy } \\
\text { Ratio } \\
\text { Total } \\
\text { capital/Total risk } \\
\text { weighted Assets }\end{array}$ & \\
\hline 2008 & & & \\
\hline 2009 & & & \\
\hline 2010 & & & \\
\hline 2011 & & & \\
\hline 2012 & & & \\
\hline 2013 & & & \\
\hline 2014 & & & \\
\hline 2015 & & & \\
\hline 2016 & & & \\
\hline 2017 & & & \\
\hline
\end{tabular}


INTERNATIONAL JOURNAL OF ACADEMIC RESEARCH IN ACCOUNTING, FINANCE AND MANAGEMENT SCIENCES

Vol. 11, No. 3, 2021, E-ISSN: 2225-8329 @ 2021 HRMARS

\section{APPENDIX: II LIST OF MICROFINANCE BANKS IN KENYA}

\begin{tabular}{|c|c|c|}
\hline No & Microfinance banks & Licensed year \\
\hline 1 & Faulu Microfinance Bank Limited & 2009 \\
\hline 2 & Kenya women Microfinance Bank limited & 2010 \\
\hline 3 & SMEP Microfinance Bank & 2010 \\
\hline 4 & Remu Microfinance Bank limited & 2010 \\
\hline 5 & Uwezo Microfinance Bank limited & 2010 \\
\hline 6 & Rafiki Microfinance Bank limited & 2011 \\
\hline 7 & Century Microfinance Bank limited & 2012 \\
\hline 8 & Sumac Microfinance Bank & 2012 \\
\hline 9 & U\& I Microfinance Bank Limited & 2013 \\
\hline 10 & Daraja Microfinance Limited & 2015 \\
\hline 11 & Choice Microfinance Limited & 2015 \\
\hline 12 & Caritas Microfinance Bank Limited & 2015 \\
\hline 13 & Maisha Microfinance bank limited & 2016 \\
\hline
\end{tabular}

